\title{
Optimizing Enzymatic Biodegradation of Skins Waste Using Response Surface Methodology
}

\author{
DANIELA SIMINA STEFAN ${ }^{1}$, CRISTINA ORBECl ${ }^{1}$, MIRCEA STEFAN ${ }^{2 *}$ \\ IUniversity Politehnica of Bucharest, 1-7 Polizu Str., 011061, Bucharest, Romania \\ ${ }^{2}$ University Titu Maiorescu, Pharmacy Faculty, Dambovnicului 22 Str., 040441, Bucharest, Romania
}

\begin{abstract}
Response surface methodology (RSM) was employed to evaluate the optimum biodegradation of pelt skin wastes (BPSW). The parameters investigated include the $\mathrm{pH}$, temperature, and enzymes mixture ratio of hydrolases, proteases and oxide - reductases on biodegradation degree for Pelt skin waste. The $\mathrm{pH}$ varied between $4.00 \pm 0.2$ and $7.00 \pm 0.2$ and temperature between $30-50^{\circ} \mathrm{C}$. Was used three mixtures tested having the following composition expressed as ratio between E1:E2:E3. M1- (1:1:1); M2-(2:1:1) and M3(3:1:1) expressed in $\mathrm{mg} / \mathrm{L}$. Response surface methodology (RSM) was used to evaluate the influence of each independent variable on the overall biodegradation efficiency of waste skin. Optimum biodegradation efficiency was achieved at $\mathrm{pH}=8.4, \mathrm{El}$ concentration in the enzyme mixture $2 \mathrm{mg} / \mathrm{L}$ and temperature 42.4 ${ }^{\circ} \mathrm{C}$. Biodegradation degree is 0.996 . Very similar results could be obtained for optimal extraction conditions using the desirability profiles available also in STATISTICA software.
\end{abstract}

Keywords: biodegradation; Pelt skin, response surface methodology, ANOVA test, optimal working parameters, STATISTICA software,

Leather manufacturing capitalize only $25 \%$ of the raw material (raw hides) the rest are waste (hair, fat, skin etc), $99 \%$ of leather waste is stored at the landfill. The capitalization of these wastes represents an area of interest in economic and environmental terms for obtaining the biocompozites, biocompost and biofertilisers [1-3].

An effective method of skin waste capitalization is protein composites obtaining by biochemical treatments with microorganisms/enzymes and obtaining of the proteinase and binders with different applications $[2,4]$. Raw hide waste resulting from fleshing, splits and pelt trimming, proteins from the solution exhausted from liming can be used for biochemical processing in the form of proteins [4-6]. Collagen, keratin and fat, contained in hide can be biodegraded of enzymes, such as lipases, oxide reductase and protease that can be used to obtaining of hydrolisates with many possibilities of capitalization, for example obtaining biofertilisers with complex composition, biostimulators [7-9].

Biodegradation of pelt skin by biochemical processes is strongly influenced by many factors such as nature of pelt waste, concentration of enzymes type in mixture, $\mathrm{pH}$, and temperature and contact time of pelt with enzymes. Conventional technique one-factor-at-a time is extremely laborious and time and reactive consuming and the optimization of process by synergistic interactions between two or more factor is unable.

For optimize the process considering all work parameters was used the statistical experimental design using response surface methodology (RMS). This methods have more application for optimizing machining techniques for chemical and biochemical process in water and wastewater treatment [9-18].

In this study we used a response surface methods (RSM) for optimizing the influence of the following variables: solution $\mathrm{pH}$, temperature and one component concentration in the enzyme mixture upon biodegradation efficiency of Pelt skin.

\section{Experimental part}

Skin samples preparation

Groups of seven numbered pieces of bovine hides wastes, cut in pieces that was about $2 \times 2 \mathrm{~cm}$, untreated, provided by tannery SC Pielorex Jilava, county Ilfov, were added into Erlenmayer flasks ( $250 \mathrm{~mL}$ capacity), in 100 $\mathrm{mL}$ of mixture of enzymes and distilled water. Erlenmayer flasks with the skin samples were inserted provided with stoppers and thermostated in a Thermoshakewith 12 plates (Incubating Shaker) at work temperature. Initial, each piece were dried at $50^{\circ} \mathrm{C}$ until reaching constant mass, and were then cooled and weighed and at various time intervals waste skin samples were taken, washed using distilled water, dried at $50^{\circ} \mathrm{C}$ until reaching constant mass and then weighed. The experiment took between 60 and $170 \mathrm{~h}$. The most representative moment for the comparative study was considered the enzymatic activity after $60 \mathrm{~h}$, in relation to which the influence of all parameters was analysed.

A thermostat shake installation has been used permitting the contact of enzymes with wastes at constant temperature and constantstirring. The $\mathrm{pH}$ values were kept constant using tampon solution acetate and ammonia and varied in accordance with a factorial design.

\section{Enzymatic mixture preparation}

In this study were have prepared 3 mixture of enzymes, using three enzymatic preparation named: E1 - mainly containing hydrolases, E2 - mainly containing deaminizes and decarboxylases and E3 -mainly containing oxidereductases. In the three mixtures we have maintained constant the concentration of E2 and E3 at $1 \mathrm{~g} / \mathrm{L}$ and, respectively, $1 \mathrm{~mL} / \mathrm{L}$. The concentration of $\mathrm{E} 1$ in the mixture was varied between 1 and $3 \mathrm{mg} / \mathrm{L}$. The three mixtures tested have the following composition expressed as ratio between E1:E2:E3. M1- (1:1:1); M2-(2:1:1) and M3-(3:1:1).

\section{Biodegradation degree \\ The biodegradation degree, $B$, was expressed as a ratio between the biodegraded waste mass, expressed in mg,}

\footnotetext{
*email: stefan_apcpm@yahoo.com
} 
and the initial mass of the waste, expressed in grams, expressed in percent:

$$
B_{d}=\frac{m_{0}-m_{b}}{m_{0}} \times 100
$$

where $B$ is the degree of enzymatic degradation, (\%)

$m$ the weight of initial Pelt skin sample dried at $50^{\circ} \mathrm{C}$ to constant weight;

$m_{b}$ the weight of Pelt skin sample after enzymatic biodegradation process, washing with distilled waterand dried at $50^{\circ} \mathrm{C}$ to constant weight.

\section{Experimental design}

Response surface methodology (RSM) was used to evaluate the influence of each independent variable on the overall biodegradation efficiency of waste skin. A BoxBehnken factorial design with three factors and three levels including three replicates at the center point was used to develop a correlation between initial enzymes concentration, temperature and $\mathrm{pH}$ and the response variable which is the overall biodegradation efficiency. This methodology allows the formulation of a second-order polynomial model to describe the process, expressed according the following equation:

$$
Y=\beta_{0}+\sum \beta_{i} x_{i}+\sum \beta_{i i} x_{i}^{2}+\sum \beta_{i i} x_{i} x_{j} \text { (2) }
$$

where $Y i$ is the response variable, $\beta$ is an intercept, $\beta i$ is the linear coefficient, $\beta_{\mathrm{i}}$ and $\beta$ are quadratic and interactive coefficients, respectively. The efficiency of the model, generated after the regression analysis of the response, was tested by ANOVA and Fisher's F-test. The interactions between variables were also represented using threedimensional response surface plots.

\section{Results and discussions}

Table 1 gives the independent factors and their values.

Table 2 describes the experimental design. The STATISTICA statistical package software trial version (Stat Soft Inc., Tulsa, USA) was used for experimental design analysis and data processing.

From table 3 one could see that the F-value model is 38.40 and corresponds to a $p$ value of 0.000436 which implies that the model is significant. Also, the model coefficient of determination has a very high value (0.985), indicating that $98.5 \%$ of the total variation is explained by this quadratic regression model. Besides, the value of the adjusted determination coefficient (Adj. $R^{2}$ ) is very high
Table 1

VARIABLES AND EXPERIMENTAL DESIGN LEVELS FOR RESPONSE SURFACE

\begin{tabular}{|l|l|c|c|c|}
\hline Independent variable & Coded symbol & \multicolumn{3}{|l|}{ Level } \\
\cline { 3 - 5 } & & -1 & 0 & 1 \\
\hline $\mathrm{pH}$ & $\mathrm{X}_{1}$ & 4 & 7 & 10 \\
\hline Temperature $\left({ }^{\circ} \mathrm{C}\right)$ & $\mathrm{X}_{2}$ & 30 & 40 & 50 \\
\hline $\begin{array}{l}\text { Concentration of E1in the } \\
\text { enzyme mixture }(\mathrm{mg} / \mathrm{L})\end{array}$ & $\mathrm{X}_{3}$ & 1 & 2 & 3 \\
\hline
\end{tabular}

Table 2

BOX-BEHNKEN EXPERIMENTAL DESIGN MATRIX OF INDEPENDENT VARIABLES AND THE CORRESPONDING EXPERIMENTAL AND PREDICTED VALUES FOR BIODEGRADATION EFFICIENCY (Y1)

\begin{tabular}{|c|c|c|c|c|c|}
\hline Run & $\mathrm{X} 1$ & $\mathrm{X} 2$ & $\mathrm{X} 3$ & Y1(exp.) & Y1 predicted \\
\hline 1 & 0 & 0 & 0 & 0.987 & 0.994 \\
\hline 2 & -1 & -1 & 0 & 0.710 & 0.707 \\
\hline 3 & -1 & 1 & 0 & 0.850 & 0.874 \\
\hline 4 & 1 & 1 & 0 & 0.904 & 0.917 \\
\hline 5 & 0 & -1 & -1 & 0.671 & 0.698 \\
\hline 6 & 0 & -1 & 1 & 0.662 & 0.672 \\
\hline 7 & -1 & 0 & -1 & 0.894 & 0.885 \\
\hline 8 & 0 & 0 & 0 & 0.987 & 0.994 \\
\hline 9 & -1 & 0 & 1 & 0.819 & 0.827 \\
\hline 10 & 1 & 0 & 1 & 0.921 & 0.940 \\
\hline 11 & 0 & 0 & 0 & 0.992 & 0.994 \\
\hline 12 & 0 & 1 & -1 & 0.827 & 0.827 \\
\hline 13 & 0 & 1 & 1 & 0.867 & 0.850 \\
\hline 14 & 1 & -1 & 0 & 0.791 & 0.777 \\
\hline 15 & 1 & 0 & -1 & 0.883 & 0.885 \\
\hline
\end{tabular}

(0.960), which means that the model is highly significant. The values of $p$ less than 0.05 indicate that the terms significant in model equation are linear terms $X 1$ and $X 2$, quadratic terms: $X 2^{2}$ and $X 3^{2}$ and interacting term $X 1 \cdot X 3$. All the other initial variables and interacting factors were not found to be statistically significant at $95 \%$ confidence limits. From Pareto chart, presented in figure 1, one could see these aspects well illustrated. So, the most significant

\begin{tabular}{|c|c|c|c|c|c|}
\hline Term & Sum of squares & DF & Mean square & $\mathrm{F}$ & $\mathrm{p}$ \\
\hline Model & 0.158619 & 9 & 0.017624 & 38.40290 & $0.000436^{2}$ \\
\hline $\mathrm{X}_{1}$ & 0.006384 & 1 & 0.006384 & 13.9116 & $0.013573^{2}$ \\
\hline $\mathrm{X}_{2}$ & 0.047125 & 1 & 0.047125 & 102.6827 & $0.000160^{2}$ \\
\hline $\mathrm{X}_{3}$ & 0.000004 & 1 & 0.000004 & 0.0098 & 0.924968 \\
\hline $\mathrm{X}_{1}{ }^{2}$ & 0.002536 & 1 & 0.002536 & 5.5262 & 0.065496 \\
\hline $\mathrm{X}_{2}{ }^{2}$ & 0.081652 & 1 & 0.081652 & 177.9176 & $0.000042^{2}$ \\
\hline $\mathrm{X}_{3}{ }^{2}$ & 0.025564 & 1 & 0.025564 & 55.7034 & $0.000682^{2}$ \\
\hline $\mathrm{X}_{1} \mathrm{X}_{2}$ & 0.000182 & 1 & 0.000182 & 0.3971 & 0.556256 \\
\hline $\mathrm{X}_{1} \mathrm{X}_{3}$ & 0.003192 & 1 & 0.003192 & 6.9558 & $0.046121^{2}$ \\
\hline $\mathrm{X}_{2} \mathrm{X}_{3}$ & 0.000600 & 1 & 0.000600 & 1.3079 & 0.304553 \\
\hline Error & 0.002295 & 5 & 0.000459 & & \\
\hline Total SS & 0.160914 & 14 & & & \\
\hline $\mathrm{R}^{2}=0.985740$ & $\mathrm{Adj} \mathrm{R}^{2}=0.960071$ & & & & \\
\hline
\end{tabular}

Table 3

ANOVA TEST FOR RESPONSE FUNCTION Y1 (BIODEGRADATION EFFICIENCY) 


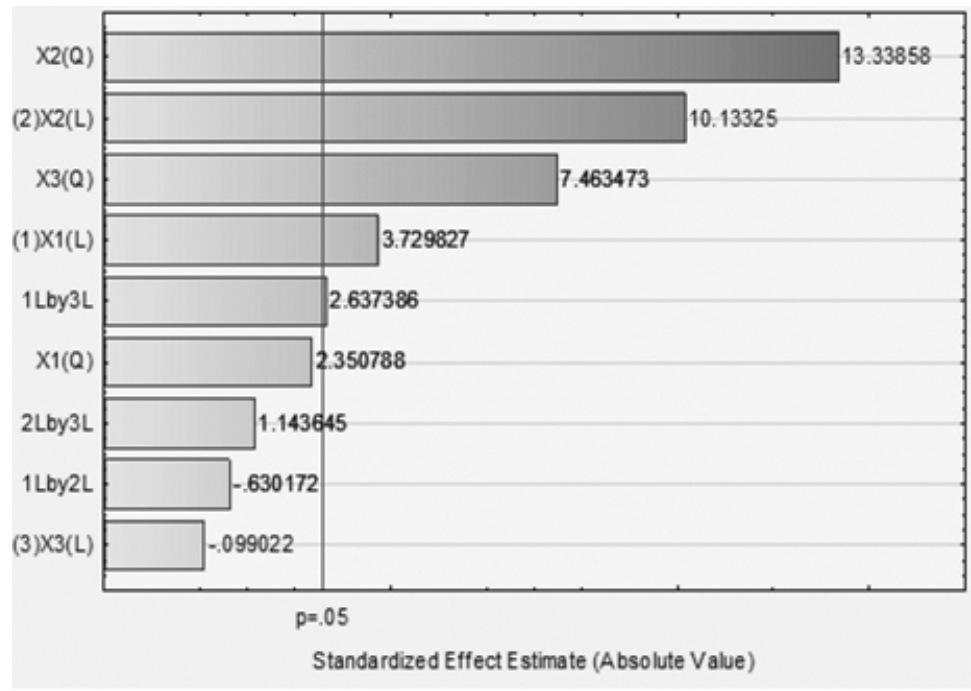

Fig. 1. Paretto chart of main effects obtained from BoxBehnken factorial design

factors which are influencing the process are: solution $\mathrm{pH}$ (only linear term), operating temperature (linear and quadratic terms), concentration of E1 in the enzyme mixture (only quadratic term) and the interacting term between solution $\mathrm{pH}$ and concentration of El in the enzyme mixture. The final equation obtained in terms of coded variables for biodegradation efficiency (Y1) is given bellow:

$$
\begin{gathered}
Y_{1}=0.98866+0.0282 X_{1}-0.02620 X_{1}^{2}+0.07675 X_{2}- \\
-0.14870 X_{2}^{2}-0.000750 X_{3}-0.08320 X_{3}^{2}-0.00675 X_{1} X_{2}^{2} 3 t \\
+0.02825 X_{1} X_{3}+0.01225 X_{2} X_{3}
\end{gathered}
$$

The fitted quadratic model simplified obtained (terms statistically insignificant, based on p-values smaller than 0.05 , were omitted) is described by equation 4 .

$$
\begin{gathered}
Y_{1}=0.98866+0.0282 X_{1}+0.07675 X_{2}-0.14870 X_{2}^{2}- \\
-0.08320 X_{3}^{2}+0.02825 X_{1} X_{3}
\end{gathered}
$$

Response surface plot from figure 2 represents the interaction between temperature and solution $\mathrm{pH}$

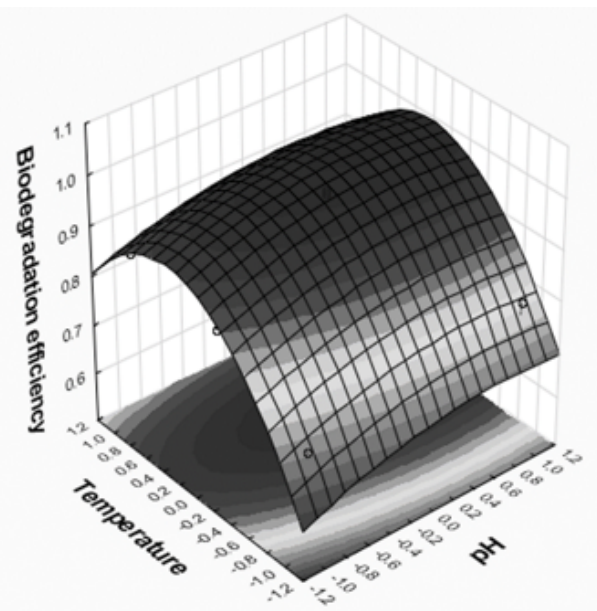

Fig. 2. Response surface plot showing the interactive effects of $\mathrm{pH}$ and temperature on biodegradation efficiency of Pelt skin. (expressed as coded variables) when the third variable (concentration of Elin the enzyme mixture) is maintained at level 0 . Figure 2 shows a significant influence on biodegradation efficiency especially of work temperature. In figure 3 is presented the response surface plot for the interaction between $\mathrm{pH}$ and $\mathrm{El}$ concentration in the enzyme mixture, when temperature is maintained at level 0 . In this case one could observe a significant influence of E1 concentration in the enzyme mixture upon biodegradation efficiency. In figure 4 one could observe that both variables temperature and E1 concentration in the enzyme mixture have a significant influence upon biodegradation efficiency of Pelt skin. Optimum biodegradation efficiency was achieved at $p H=8.4$, E1 concentration in the enzyme mixture $2 \mathrm{mg} / \mathrm{L}$ and temperature $42.4^{\circ} \mathrm{C}$. Very similar results could be obtained for optimal extraction conditions using the desirability profiles available also in STATISTICA software. In figure 5 are presented the desirability profiles obtained for biodegradation of Pelt skin.

The experiments were carried out to validate the model prediction. Under the above conditions, the value obtained for biodegradation efficiency was 0.996 in a good agreement with theoretical predictions.

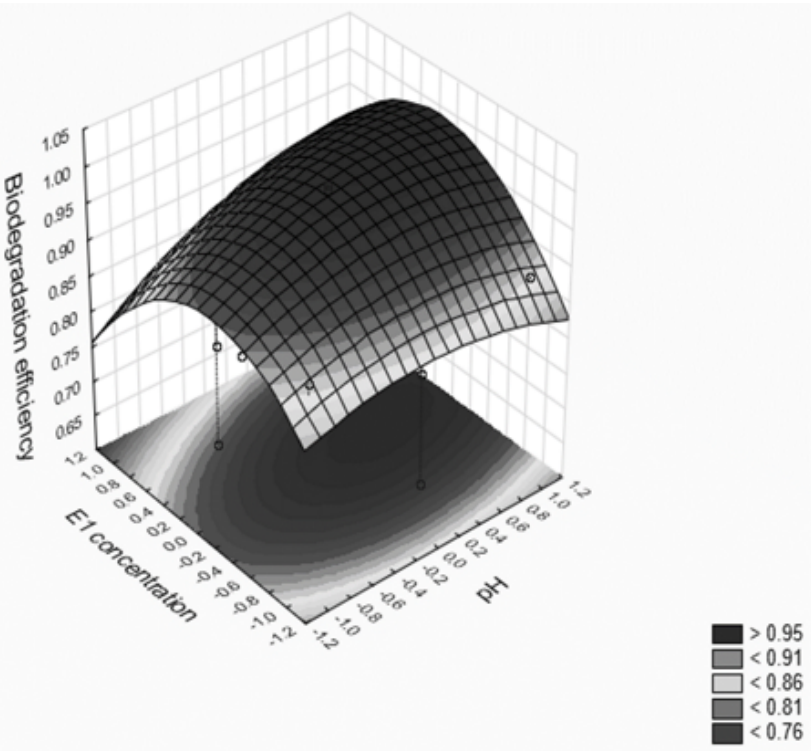

Fig. 3. Response surface plot showing the interactive effects of $p H$ and $\mathrm{El}$ concentration in the enzyme mixture on biodegradation efficiency of Pelt skin. 


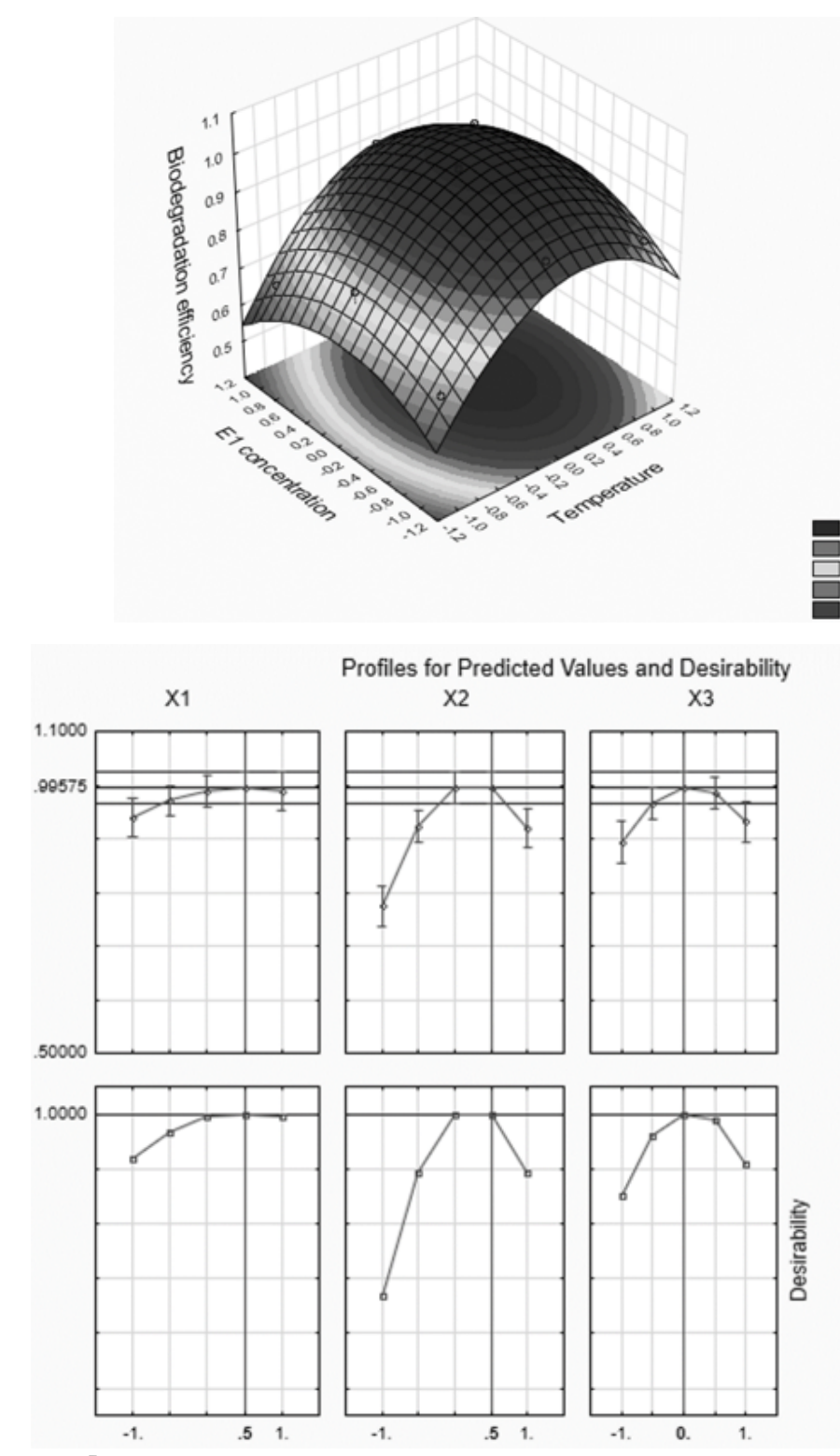

Fig. 4. Response surface plot showing the interactive effects of temperature and E1 concentration in the enzyme mixture on biodegradation efficiency of Pelt skin.

Fig. 5. Profiles for predicted biodegradation efficiency and the desirability level for different influencing factors for optimum biodegradation of Pelt skin.

b. NAINCY G., LHAUHAN P.S., KUMAR V., PURI N., GUPTA N. J., Clean Prod., 79, 2014, p. 249

7. SARAN S, MAHAJ AN R.V., KAUSHIK R., ISAR J ., SAXENA R.K., J. Clean Prod., 54, 2013, p. 315.

8. STEFAN, D.S., CONSTANTINESCU, R.R., MEGHEA, A., ANGHEL, R., STEFAN, M., TUDOSIE, M.S., Rev. Chim.(Bucharest), 67, no 7, 2016, p. 1401.

9.ADINARAYANAK K., ELLAIAH P., SRINIVASULU B., DEVI L., TSENG DH, HUANG S.L., Biotechnol. Lett., 23, no. 20, 2001, p. 1653-1657.

10. AHMAD A.L., ISMSIL S., BHATIA S., Environ Sci Technol., 39, no. 8, 2005, p. 2828.

11. STOICA-GUZUN A., STROESCU M., JINGA. S.I., MIHALACHE N., BOTEZ A., CRISTIAN M., BERGER D., DAMIAN C.M., VALENTIN I., Int. J. Bio.l Macromol., 91, 2016, p. 1062.

12. GAN C.Y., MANAF N.H.A., LATIFF A.A., Carbohydr. Polym., 79, no 4, 2010, p. 825.

13. PINGRET D., FABIANO-TIXIER A.S., LE BOURVELLEC C., RENARD M.G.C., CHEMAT F., J. Food. Eng., 111, no. 1, 2012, p. 73.

14. STROESCU M., STOICA-GUZUN A., GHERGU S., CHIRA N., JIPA I., Ind., Crop. Prod., 43, 2013, p. 405.

15. BOUCHEZ M., BLANCHET D., VANDECASTLE J .P., Appl. Microbiol. Biotechnol., 43, no 1, 1995, p. 156.

16. MURTHY M.S.R.C., SWAMINATHAN T., RAKSHIT K.Y., Bioprocess Eng., 22, no 1, 2000, p. 35.

17. ORLITA A., Microbial biodeterioration of leather and its control: A review. Int. Biodeterior. Biodegrad., 53, no 3, 2004. p. 157.

18. WU S., YU X., HU Z., ZHANG L., CHEN J., J. Environ, Sci., 21, no 9, 2009, p. 1276.

5. PANTAZI, M., STEFAN, D. M., CONSTANTINESCU, R.,VASILESCU, A M., Rev Chim(Bucharest), 65, 2014, p. 233. 